\title{
Organic and inorganic geochemical study of the Lower Permian Walchia shale of the Intrasudetic Basin (SW Poland)
}

\author{
Elżbieta BILKIEWICZ ${ }^{1, *}$, Jadwiga PIECZONKA ${ }^{1}$ and Adam PIESTRZYŃSKI ${ }^{1}$ \\ 1 Faculty of Geology, Geophysics and Environmental Protection, AGH University of Science and Technology, \\ al. A. Mickiewicza 30, 30-059 Kraków, Poland
}

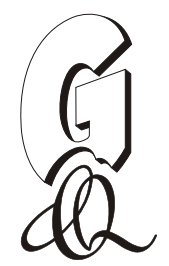

Bilkiewicz, E., Pieczonka, J., Piestrzyński, A., 2018. Organic and inorganic geochemical study of the Lower Permian Walchia shale of the Intrasudetic Basin (SW Poland). Geological Quarterly, 62 (3): 631-643, doi: 10.7306/gq.1427

Associate editor: Stanisław Wołkowicz

The Lower Permian Walchia shale of the Intrasudetic Basin is lacustrine sediment enriched in organic matter and base metals. Rock-Eval geochemical analysis was conducted on 110 drill-core rock samples of the Walchia shale in order to characterize the quantity, genetic type and maturity of dispersed organic matter. Concentrations of U, Th, $\mathrm{Cu}, \mathrm{Ni}, \mathrm{V}, \mathrm{Pb}, \mathrm{Zn}, \mathrm{Co}, \mathrm{Mo}$, $\mathrm{Cr}, \mathrm{P}, \mathrm{S}$ and $\mathrm{Fe}$ were determined and microscopic studies to recognize mineral composition were performed on selected samples. Organic matter of the Walchia shale is immature and dominated by terrestrial type III kerogen with an admixture of planktonic type II kerogen. The Walchia shale is generally poor source rock, but some parts of the profile exhibit good and even excellent hydrocarbon potential. The average concentrations of analysed metals are higher than the average reported for black shales. The concentrations of base metals do not correlate with TOC contents, suggesting that their presence is associated with inorganic features of the Walchia shale or they could have been related primarily to organic matter which was subsequently oxidized and altered. Uranium may be partly associated with phosphates. Results of microscopic investigations revealed the lack of detectable radioactive minerals, abundance of framboidal pyrite, and prevalent galena, sphalerite and chalcopyrite.

Key words: Intrasudetic Basin, Walchia shale, organic matter, uranium, base metal mineralisation.

\section{INTRODUCTION}

Some shales, especially black shales, are known for their elevated concentrations of minor elements, which can exceed more than a hundred and even thousand times their average crustal abundance (e.g., Krauskopf, 1955; Vine and Tourtelot 1970). Metals occurring in shales can be associated with sulphides, organic matter and/or clay minerals and are accumulated syngenetically, during diagenesis, or can be mobilized epigenetically and moved to new places (Leventhal, 1993). Metal enrichment in sedimentary rocks results from mechanical enrichment, adsorption, chemical precipitation and processes involving organic matter (Krauskopf, 1955).

The Walchia shale is a noteworthy rock unit composed mainly of dark mudstones and shales, locally carbonaceous, known for its uranium and organic matter enrichment (Wołkowicz, 1990; Yawanrajah et al., 1993). The lacustrine dark sediments of the Walchia shale were deposited in variable sedimentary environ-

\footnotetext{
* Corresponding author, e-mail: ebil@agh.edu.pl
}

Received: January 23, 2018; accepted: April 16,2018, first published online: September 12, 2018 ments and under changing conditions during the Early Permian within the Intrasudetic Basin (Wołkowicz, 1988).

The main objective of this study was to define the organic and inorganic characteristics of the Walchia shale by determining the quantity, genetic type, thermal maturity and hydrocarbon potential of dispersed organic matter based on results of Rock-Eval geochemical analysis, concentrations of selected elements ( $\mathrm{U}$, Th, $\mathrm{Cu}, \mathrm{Ni}, \mathrm{V}, \mathrm{Pb}, \mathrm{Zn}, \mathrm{Co}, \mathrm{Mo}, \mathrm{Cr}, \mathrm{P}, \mathrm{S}$ and $\mathrm{Fe}$ ) and their expression in mineral composition. Moreover, several inorganic and organic redox proxies have been implemented to interpret the conditions during deposition of the Walchia shale. Previous studies concerning Walchia shale geochemistry (Wołkowicz, 1990) indicated a close relationship between organic matter content and uranium concentrations, suggesting their syngenetic occurrence. This paper is an attempt to re-evaluate previous investigations on the organic matter role in the formation of uranium mineralisation in the Walchia shale, as well as to search for other relationships between organic-inorganic features of this strata and metallic mineralisation.

\section{GEOLOGICAL SETTING}

The study area is located in the SE part of the Intrasudetic Basin (ISB) between the town of Radków and the village of Wambierzyce, covering $\sim 2.3 \mathrm{~km}^{2}$ (Fig. $1 \mathrm{~A}$ ). The ISB is a 


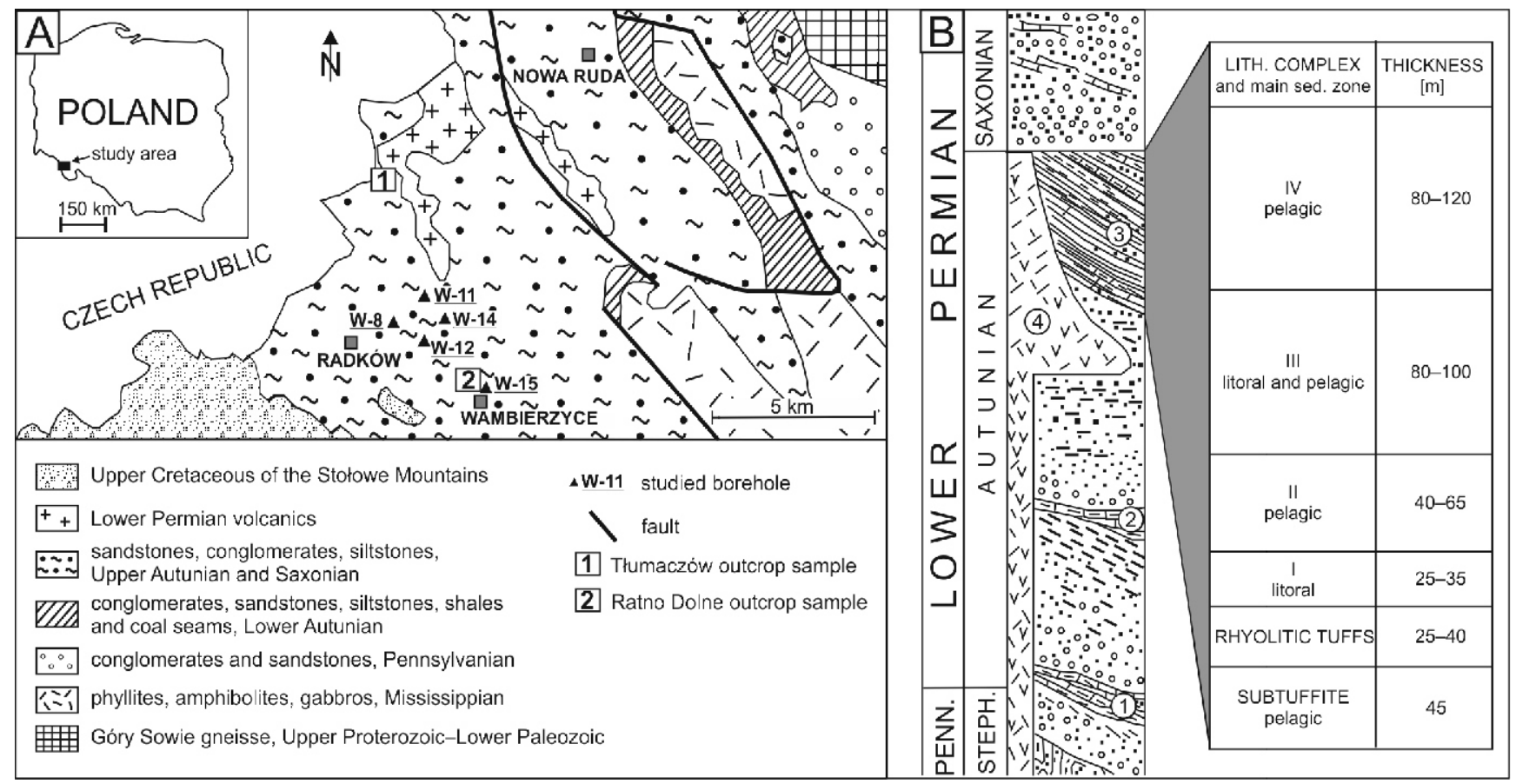

Fig. 1A - geological sketch-map of the study area (modified after Augustyniak and Grocholski, 1968; Nemec et al., 1982; Speczik et al., 1995); B - the Walchia shale position in the lithostratigraphic profile of the Lower Permian of the Intrasudetic Basin (modified after Mastalerz and Wojewoda, 1988; Nowak, 2007), with the Walchia shale lithological division and prevailing depositional environment (after Wołkowicz, 1992)

W-8 - Wambierzyce IG 8 borehole; W-11 - Wambierzyce IG 11 borehole; W-12 - Wambierzyce IG 12 borehole; W-14 - Wambierzyce IG 14 borehole; W-15 - Wambierzyce IG 15 borehole; 1 - Lower Anthracosia shale, 2 - Upper Anthracosia shale, 3 - Walchia shale, 4 - volcanites and volcanoclastics; Penn. - Pennsylvanian; Step. - Stephanian (stage defined regionally in European stratigraphy, corresponding to the Gzhelian); lith. - lithological; sed. - sedimentary

NW-SE-trending oval intramontane trough, $70 \mathrm{~km}$ long and $35 \mathrm{~km}$ wide, formed in the Early Mississippian on the periphery of the Bohemian Massif as a result of Variscan evolution of the Sudetes. The synclinorial structure of ISB is separated from surrounding, uplifted, mostly crystalline, tectonic units by fault zones, which were active during its development (Speczik et al., 1995). The ISB is filled with a few km thick Lower Mississippian to Lower Permian volcano-sedimentary succession and overlain by Lower Triassic and Upper Cretaceous deposits of continental and marine origin, respectively (Awdankiewicz et al., 2003; Bossowski and Ihnatowicz, 2006). Material deposited within the ISB was fed from metamorphic complexes of the Kaczawa and Rudawy Janowickie ranges and the hypothetical "Southern Massif", which were rapidly uplifted during Variscan movements and then intensely eroded during the Early Mississippian subperiod (Teisseyre, 1975; Awdankiewicz et al., 2003).

Within the monotonous, thick, coarse-grained continental Lower Permian (Rotliegend) sediments, containing volcanic and pyroclastic rocks, three distinct lacustrine sequences consisting of organic-rich mudstones and claystones with some limestone intercalations occur as end-members of sedimentary cyclothems. Conglomerates and sandstones deposited in oxic environments pass progressively into the calcareous, sandy claystones and mudstones of lacustrine origin, which are recognized as the Lower and Upper Anthracosia and Walchia shales (Speczik et al., 1995; Fig. 1B). The Lower and Upper Anthracosia shales represent the uppermost Pennsylvanian/Autunian and Autunian, respectively (Jerzykiewicz, 1987; Górecka-Nowak, 2008; Górecka-Nowak and Nowak, 2008), while the Walchia shale was deposited on top of the third cyclothem at the end of the Autunian (Jerzykiewicz, 1987; Mastalerz and Wojewoda, 1988; Speczik et al., 1995; Fig. 1B). The Anthracosia shales are distinguished by their organic matter and Cu enrichment (Speczik et al., 1995 and references therein), whereas the Walchia shale sediments have been studied owing to their U enrichment (Wołkowicz, 1990, 1992). The issues of uranium mineralisation in the Walchia shale were discussed by Miecznik and Strzelecki (1979), Bareja et al. (1982), Miecznik (1989) and Wołkowicz (1990, 1992). The Walchia shale occurs in the Upper Autunian strata (Fig. 1B) and belongs to the Słupiec Formation, Ratno Dolne Member (Wołkowicz, 1990), which is equivalent to the Broumov Formation, Olivětin Member, in the Czech part of ISB (Tásler et al., 1979). It reaches a thickness of $300-350 \mathrm{~m}$ dipping $\sim 15^{\circ} \mathrm{SW}$ towards the basin centre (Radwański, 1955; Wołkowicz, 1992; Speczik et al., 1995). The Walchia shale is rich in organic matter, especially the plant remains of Walchia piniformis from which their name is derived. Wołkowicz $(1988,1990,1992)$ distinguished five complexes varying in lithology (Fig. 1B), recognizing horizons enriched in uranium within four of them. Their further description is after that author. At the base of the Walchia shale succession there is a subtuffite complex composed of mudstones and sandstones containing two carbonate layers. These rocks were deposited mostly in oxidized pelagic zone of the lake. The subtuffite complex is covered by a 25-40 m thick horizon of rhyolitic tuffs. The oxidized brown-red sandstones of complex I were deposited in the littoral zone and demonstrate bioturbation. Sediments of complex I overlie rhyolitic tuffs throughout the area, reaching a thickness of $35 \mathrm{~m}$. Within this 
complex, no uranium horizons have been reported. Sediments of complex II form a 40-65 m thick series of black mudstones with intercalations of bituminous limestones, deposited in an anoxic pelagic environment. Within this complex, asphaltite lenses have been found. Complex III is composed of variable red sandstones to siltstones and grey-black claystones passing into mudstones which are usually calcareous. Rocks of this complex contain high amounts of organic matter (up to 10\%) The variations in lithology resulted from rapid environmental changes from a littoral through a coastal plain to a pelagic zone, where grey to black claystone-mudstone sediments were deposited. Complex IV is the uppermost series of the Walchia shale and consists of black claystones and mudstones intercalated by sandstone-mudstone layers and carbonate laminae occurring at its basal part. This complex reaches a thickness of up to $120 \mathrm{~m}$ and the sediments were deposited in both oxic and anoxic zones of the basin.

\section{ROCK SAMPLING AND PREPARATION PROCEDURE}

Due to strong weathering, confirmed latterly by Rock-Eval (RE) results on samples taken from outcrops at the Tłumaczów and Ratno Dolne localities (Fig. 1A), the studies were limited to samples derived from boreholes. A total of 110 drill-core rock samples of the Walchia shale have been collected from the Wambierzyce IG 8, Wambierzyce IG 11, Wambierzyce IG 12, Wambierzyce IG 14 and Wambierzyce IG 15 boreholes, covering an area of $\sim 2.3 \mathrm{~km}^{2}$ (Fig. 1A). The collected rock samples represent all lithological complexes identified within the Walchia shale sequence: complex IV (43 samples), complex III (15 samples), complex II (31 samples), complex I (2 samples) and subtuffite complex (19 samples). The subdivision of the Walchia shale into complexes, proposed by Wołkowicz (1988), has been implemented for the present study and the rock samples have been divided and identified according to the above-mentioned lithological criteria.

The sampling was restricted to relatively dark and fine-grained parts of the cores. Upon arrival to the laboratory, rock samples were crushed to the fraction $<2 \mathrm{~cm}$, then homogenized and a representative portion of $\sim 100 \mathrm{~g}$ was pulverized to the fraction $<0.2 \mathrm{~mm}$ for RE pyrolytic analysis. For multi-element concentration analysis a representative portion of a crushed sample was pulverized to the fraction $<0.1 \mathrm{~mm}$ and a portion of $\sim 4 \mathrm{~g}$ was poured off and sent for analysis. Microscopy analysis was performed on polished sections of gravel-size samples.

\section{ANALYTICAL PROCEDURE}

\section{ROCK EVAL PYROLYSIS}

The RE pyrolysis is a standard technique used in petroleum exploration for characterizing organic matter in sedimentary rocks. The RE method allows for preliminary determination of hydrocarbon potential and identification of the amount, type and maturity of organic matter. The RE pyrolysis was completed with a Vinci Technologies Rock-Eval 6 Turbo apparatus on all collected rock samples. The details of the analysis are de- scribed in Lafargue et al. (1998). For preliminary characterization of organic matter of the Walchia shale the following parameters and indices have been used: total organic carbon content (TOC, wt. \%), $S_{1}$ and $S_{2}$ referred to as free and residual hydrocarbon contents, respectively (mg HC/g rock), hydrogen index $-\mathrm{HI}$ (mg HC/g rock), oxygen index - Ol (mg HC/g rock), and $T_{\max }\left({ }^{\circ} \mathrm{C}\right)$ obtained at maximum of $\mathrm{S}_{2}$ peak which corresponds to the thermal maturity of organic matter.

\section{MULTI-ELEMENT ANALYSIS}

In total, 49 rock samples have been analysed for elemental concentrations (Appendix 1*). The samples were selected by quantitative organic matter content (high TOC contents) and statistical criteria according to lithology. The concentrations of $\mathrm{U}$, Th, $\mathrm{Cu}, \mathrm{Ni}, \mathrm{V}, \mathrm{Pb}, \mathrm{Zn}, \mathrm{Co}, \mathrm{Mo}, \mathrm{Cr}, \mathrm{P}, \mathrm{S}$ and Fe were determined by inductively coupled plasma-mass spectrometry (ICP-MS) technique. The analysis is performed by digestion of powdered samples to complete dryness with an acid solution of (2:2:1:1) $\mathrm{H}_{2} \mathrm{O}-\mathrm{HF}-\mathrm{HClO}_{4}-\mathrm{HNO}_{3}$. Then, the residue is dissolved in $50 \% \mathrm{HCl}$ and heated using a mixing hot block. After cooling, the solutions are transferred to test-tubes, brought to volume using dilute $\mathrm{HCl}$, and analysed by ICP-MS. The detection limits are $0.1 \mathrm{ppm}$ for $\mathrm{U}, \mathrm{Th}, \mathrm{Cu}, \mathrm{Pb}, \mathrm{Ni}$ and $\mathrm{Mo}, 0.2 \mathrm{ppm}$ for $\mathrm{Co}$, $1.0 \mathrm{ppm}$ for $\mathrm{Zn}, \mathrm{V}$ and $\mathrm{Cr}, 0.1 \%$ for $\mathrm{S}, 0.01 \%$ for $\mathrm{Fe}$, and $0.001 \%$ for $\mathrm{P}$. For quantification of the results, the following reference materials were used: DS11and OREAS 45Ea internal standards for aqua regia digestion, SO-19 internal standard for whole-rock analysis, and GS 910-4 and GS 311-1 certified standards for sulphur and carbon assays. The elemental analysis was performed by Bureau Veritas Mineral Laboratories in Vancouver, Canada.

\section{MICROSCOPY STUDIES}

Microscopy studies were made on Walchia shale samples selected based on results of previous analyses. The studies were performed on polished sections of rock samples with the highest TOC contents and $U$ and Th concentrations (Appendix 1). In total, 15 rock samples were investigated in reflected light using a NIKON optical microscope. Additionally, two samples with the highest $U$ concentrations were analysed using an EDS (energy-dispersive spectroscopy) system combined with an electron scanning microscope FEI Quanta-200 FEG (20 kV acceleration voltage)

\section{RESULTS AND DISCUSSION}

\section{GEOCHEMICAL CHARACTERISTICS OF ORGANIC MATTER}

Results of RE pyrolysis were used to determine the quantity, genetic type and thermal maturity of organic matter dispersed in the Walchia shale. The minimum, maximum and average values of RE TOC content (wt. \%), $\mathrm{S}_{2}$ (mg HC/g rock), hydrogen index $(\mathrm{HI}, \mathrm{mg} \mathrm{HC} / \mathrm{g}$ rock) and mineral carbon (MinC, wt.\%) for each sampled complex are presented in Table 1. Rock samples with low TOC values, $<0.2 \mathrm{wt} . \%$, are generally considered as not providing reliable RE data, therefore the RE parameters and indices from only 56 samples have been used for interpretation and were assessed as valid (Figs. 2 and 3).

* Supplementary data associated with this article can be found, in the online version, at doi: 10.7306/gq.1427 


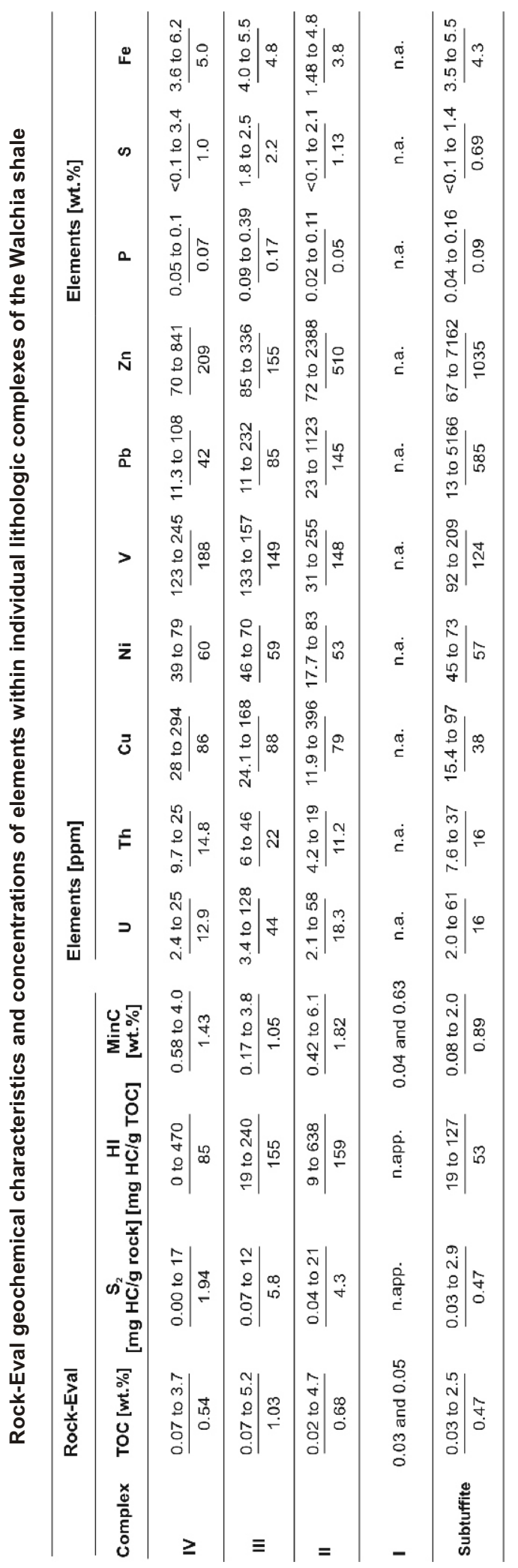

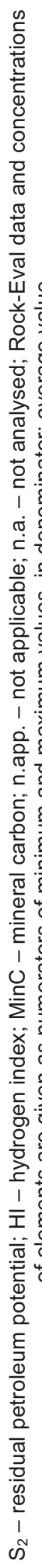
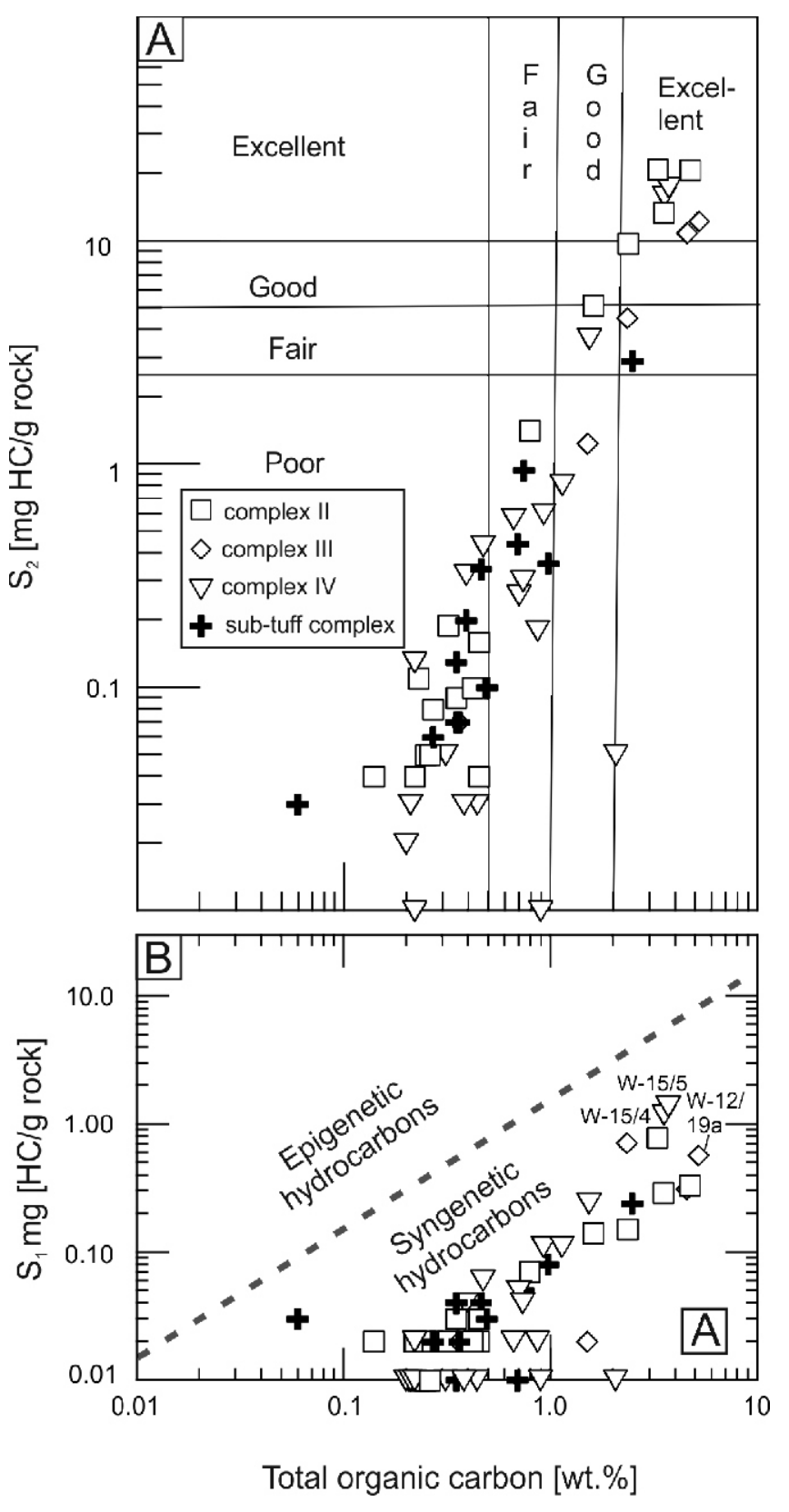

Fig. 2A - Rock-Eval free hydrocarbon $S_{1}$ parameter; $B-S_{2}$ residual petroleum potential versus total organic carbon content (TOC) of organic matter of the Walchia shale

Petroleum source quality according to criteria of Peters and Cassa (1994); genetic boundary after Hunt (1996); key for sample codes see Appendix 1

Higher contents of MinC, up to 6.1 wt.\% in complex II (Table 1), represent calcareous interbeds and cements within the mudstone-claystone sequence of the Walchia shale, indicating local influence of carbonate sedimentary conditions.

The RE pyrolysis revealed that the organic matter dispersed in the Walchia shale shows neither distinct vertical zonation of organic geochemical parameters nor significant geochemical differences between particular lithological complexes (Table 1, Appendix 1 and Figs. 2-4A) with one exception of complex I, which is coarse-grained and poor in organic matter and was sampled only for comparison purposes. However, geochemical characteristics of the Walchia shale organic matter are not uni- 


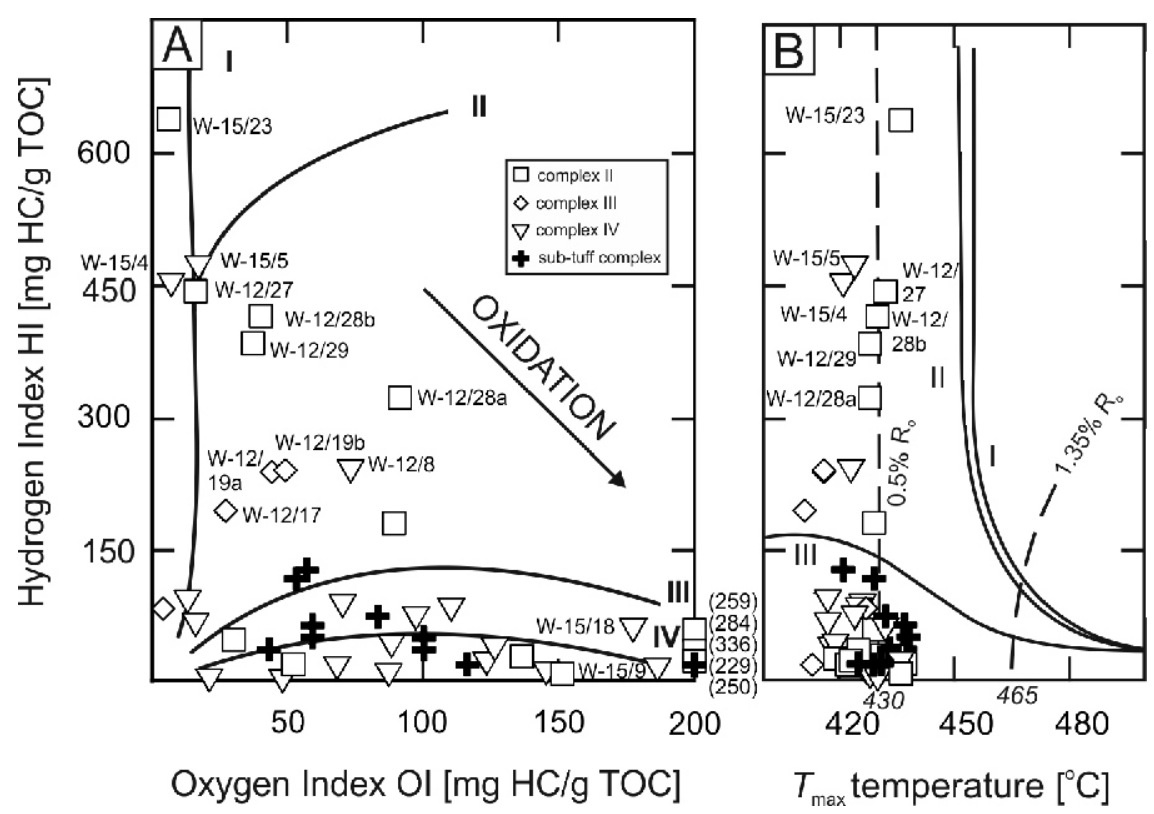

Fig. 3. HI versus (A) OI and (B) $T_{\max }$ temperature based on Rock-Eval pyrolysis of the Walchia shale

Genetic pathways after Espitalié et al. (1985); key for sample codes see Appendix 1

form, as being the result of variable conditions and depositional environments within the lacustrine basin.

According to Peters and Cassa's criteria (1994) for source quality of organic matter the results of RE pyrolysis indicate that the Walchia shale is generally a poor source rock as described by a TOC median value of $0.22 \mathrm{wt} . \%$ and an average value of $0.61 \mathrm{wt} . \%$ for the whole analysed sequence. The TOC contents change in a wide range from $0.02 \mathrm{wt} . \%$ in complex II to $5.2 \mathrm{wt} . \%$ in a calcareous shale sample representing complex III (Table 1 and Appendix 1). Residual hydrocarbons contents vary from $0.00 \mathrm{mg} \mathrm{HC} / \mathrm{g}$ rock in complex IV to $21 \mathrm{mg} \mathrm{HC} / \mathrm{g}$ rock in complex II (Table 1 and Fig. 2A). The highest $S_{2}$ content of $21 \mathrm{mg} / \mathrm{g}$ rock and the highest $\mathrm{HI}$ value (resulting from high $\mathrm{S}_{2}$ content) of $638 \mathrm{mg} / \mathrm{g}$ rock have been measured in the claystone sample $\mathrm{W}-15 / 23$ (Appendix 1). The highest average $S_{2}$ content of $5.8 \mathrm{mg} \mathrm{HC} / \mathrm{g}$ rock is observed in the samples representing complex III (Table 1). Locally high TOC values, $>1$ wt. \%, accompanied by elevated residual hydrocarbons contents, $>2.5 \mathrm{mg} \mathrm{HC} / \mathrm{g}$ rock, indicate fair to even excellent petroleum potential (Fig. 2A). These samples represent sediments deposited likely in pelagic, anoxic parts of the basin. Rocks of complexes III and II respectively show the best hydrocarbon potential, as indicated by $\mathrm{S}_{2}$ and $\mathrm{HI}$ values (Table 1, Figs. 2 and 3). Taking into account criteria proposed by Hunt (1996; Fig. 2B) and Espitalié et al. (1977; 1985; PI > 0.5 for epigenetic HC) for identification of migrating or contaminating hydrocarbons, all hydrocarbons accumulated within the Walchia shale are only syngenetic, and therefore were generated exclusively from organic matter of the Walchia shale. Enriched in organic matter, sediments of the Walchia shale were deposited likely due to favourable anoxic depositional conditions and low sedimentation rates. Occasionally, the sediments were deposited in high-energy environments which might be related to flood episodes in the basin, resulting in deposition of thicker, coarser and oxidized layers found in complex I. Rapid sedimentation also resulted in diluting organic matter.

Plotting $\mathrm{HI}$ against $\mathrm{Ol}$ and $T_{\max }$ values (Fig. 3) on the diagnostic diagrams (Espitalié et al., 1985) indicates the presence of at least two genetic groups of organic matter. According to these diagrams (Fig. 3) most of the analysed samples contain organic matter with dominant terrestrial type III kerogen being derived from vascular plants, whose remnants (e.g., Walchia piniformis, Callipteris confereta) have been previously reported in the sediments of the Walchia shale (Kurowski, 2004 and references therein). However, 10 rock samples, representing complexes II, III and IV, show high $\mathrm{HI}$ values, exceeding $200 \mathrm{mg} \mathrm{HC} / \mathrm{g}$ rock, which evidences an admixture of planktonic lacustrine type II kerogen, but some contribution of algal type I kerogen cannot be excluded as well (Fig. 3). Petrographic and palynological studies of organic matter in the Walchia shale (Górecka-Nowak and Nowak, 2008) indicated that fine-grained sediments representing deeper parts of the basin are dominated by sapropelic organic matter, whereas humic organic matter, composed mainly of vitrinite, prevails in coarser sediments, most likely representing shallower zones of the lake. These observations agree with conclusions reported by Wołkowicz (1990), obtained from $n$-alkane distribution showing dominance of $\mathrm{C}_{16}-\mathrm{C}_{18}$ and $\mathrm{C}_{25}$ hydrocarbons which are derived from algae-bacterial and vascular plant organic matter, respectively. The $T_{\max }$ values within the range of $411-438^{\circ} \mathrm{C}$ (Appendix 1) and the PI value (not exceeding 0.4 ) indicate that organic matter is immature. This is also in agreement with CPI data published by Wołkowicz (1990) and $R_{o}$ data reported by Górecka-Nowak and Nowak (2008).

Hydrocarbon type index expressed as $S_{2} / S_{3}$ ratio of most samples exhibits values below 2 indicating predominance of gas-prone organic matter, however in nine samples this ratio exceeds 5 corresponding to the oil-type organic matter (Appendix 1; Hunt, 1996). High Ol values, exceeding $150 \mathrm{mg} / \mathrm{g}$ TOC, may evidence oxidation of organic matter. Low HI accompanied with high OI values may suggest the influence of secondary oxidation processes related to radiolytic degradation of organic matter, which is a frequent phenomenon in uranium deposits (Landais, 1996), but such interpretation for the strata is rather unlikely due to low $\mathrm{U}$ concentrations. Moreover, high $\mathrm{OI}$ values are accompanied by low TOC contents, which may evidence 


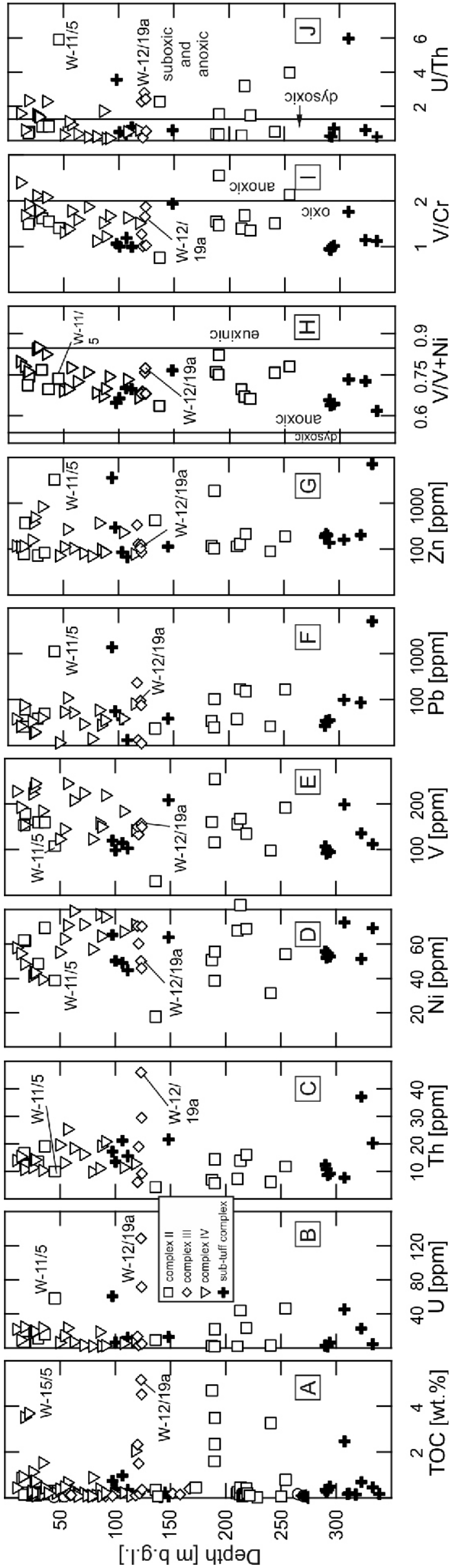

partial oxidation of rocks as observed by e.g., Pieczonka et al. (2008) in Upper Permian Kupferschiefer strata and Więcław (2016) in Kimmeridgian strata of the Polish Lowlands. Low HI values are associated with low TOC contents, which may result from organic matter dispersion within the sediment, known as "mineral matrix effect" (e.g., Więcław, 2016).

\section{MULTI-ELEMENT ANALYSIS OF ROCK SAMPLES}

The concentrations of analysed elements in the Walchia shale samples differ considerably (Table 1, Appendix 1 and Figs. 4B-9), but mostly show high amounts, greater than those reported for average shale (Turekian and Wedepohl, 1961) and even average black shale (Vine and Tourtelot, 1970; Quinby et al., 1989), being similar to data reported for the Antrim Shale from the Michigan Basin (Leventhal, 1993), and generally significantly higher than data reported by Speczik et al. (1995) for the Anthracosia shales. The maximum, minimum and average concentrations of these elements are shown in Table 1, and the variations of their concentrations and ratios with depth are shown in Figure 4B-J. The highest average contents of $U$, Th, $P$ and $\mathrm{Cu}$ have been measured in rock samples representing complex III, reaching $44 \mathrm{ppm}, 22 \mathrm{ppm}, 0.17 \%$ and $88 \mathrm{ppm}$, respectively (Table 1, Appendix 1, Figs. 4B, C and $5 A-C$ ). The highest $U$ concentrations reach 128 ppm in complex III (sample W-12/19a, Table 1, Appendix 1, Figs. 4B and 5A). This enrichment is associated with the highest TOC content, which suggests that organic matter may hold $\mathrm{U}$, while high $\mathrm{HI}$ and low $\mathrm{Ol}$ values (Appendix 1 and Fig. 3) prove reducing conditions conducive to uraninite precipitation from relatively oxidized U-bearing solutions. Wołkowicz (1990) also reported maximum U concentrations in rocks of complex III, however much higher (up to $500 \mathrm{ppm}$ ), linking the mineralisation with laminated black calcareous shales containing laminae and streaks of organic matter, dispersed galena and pyrite, and asphaltite lenses. The lowest average concentration of $U(12.9 \mathrm{ppm})$ was observed in rocks representing complex IV, which is also consistent with results reported by Wołkowicz (1990). Uranium and thorium concentrations for ordinary shales reported by Turekian and Wedepohl (1961) are $3.5 \mathrm{pm}$ and $12 \mathrm{ppm}$, respectively. Data obtained for the Walchia shale are reverse, higher contents have been recorded for $U$ than for Th, as with data reported for Kupferschiefer strata where this difference is assumed to be caused by secondary enrichment in $U$ derived from the Rotliegend (Piestrzyński, 1990). So far, the U enrichment in the Walchia shale, like in the Kupferschiefer, have been considered associated with organic matter (Wołkowicz, 1990, 1992; Piestrzyński, 1990 and references therein). Average U concentrations obtained for individual complexes of the Walchia shale are higher than the average $15 \mathrm{ppm}$ reported for black shales (Quinby et al., 1989) except for the average for complex IV (Table 1). Plotting the $U$ concentration with the TOC content (Fig. 5A) does not exactly support this thesis; however, the highest $U$ concentration of $128 \mathrm{ppm}$ was recorded in the sample with the highest TOC content (5.2 wt.\%; Appendix 1). More-

Fig. 4. Depth variation of (A) total organic carbon content (TOC), $U$ concentration (B), Th concentration (C), Ni concentration (D), $V$ concentration (E), $P b$ concentration $(F), Z n$ concentration (G), $\mathrm{V} /(\mathrm{V}+\mathrm{Ni})$ ratio $(\mathrm{H}), \mathrm{V} / \mathrm{Cr}$ ratio $(\mathrm{I})$ and $\mathrm{U} / \mathrm{Th}$ ratio $(\mathrm{J})$ of the Walchia shale samples

Depositional settings after Hatch and Leventhal (1992) and Jonnes and Manning, (1994); b.g.l. - below ground level; key for sample codes see Appendix 1 

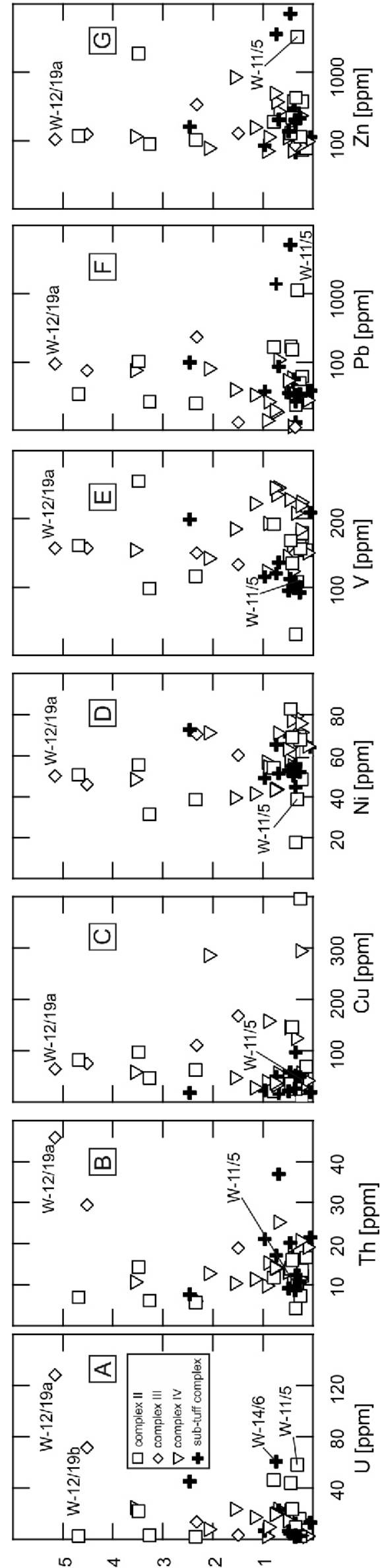

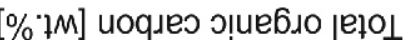

over, no correlation occurs between the $U$ concentrations and $\mathrm{HI}$ for all the rock samples, but it does exist for the subtuffite complex (Appendix 1). These observations suggest that $U$ mineralisation is associated with organic matter dominated by a genetic component of type III kerogen that prevails in the subtuffite complex (Fig. 3). On the other hand, the third highest $\mathrm{U}$ content of $61 \mathrm{ppm}$ was recorded in a sample representing the subtuffite complex with a TOC content of only $0.74 \mathrm{wt} \%$ (Appendix 1 and Fig. 5A). The correlation between the TOC and $U$ contents is not clearly observable, neither in the whole rock population $\left(R^{2}=0.23\right)$ nor in the individual complexes, and may be limited only to some parts within the Walchia shale without indicating any particular complex (Fig. 5A). This suggests that the $U$ occurrence within the Walchia shale is related to and controlled by more factors than only associated with organic matter. This thesis is supported by the correlations between the $U$ and $\mathrm{P}$ concentrations (Fig. 6A) and between the Th and P concentrations (Fig. 6B), which indicate that the presence of $U$ and Th in the Walchia shale is likely related to phosphate minerals, e.g., apatite (described in the next chapter). Uranium often accompanies phosphate rocks, especially those of sedimentary origin (e.g., Schnug and Haneklaus, 2014). Tetravalent uranium $\left(\mathrm{U}^{4+}\right)$ can substitute for $\mathrm{Ca}$ in the apatite lattice and accumulate in carbonaceous material accompanying phosphates (Baturin and Kochenov, 2001; Dill, 2011 and references therein). Marine phosphorite deposits contain $U$ usually below $100 \mathrm{ppm}$, whereas organic phosphorites can contain $U$ up to 600 ppm (Dill and Kantor, 1997; Dill, 2011). The most important representative of $U$ deposits in marine phosphorites occurs in Khouribga, Morocco (Oulad Abdoun Basin), and in organic phosphorites at Melovoe, Kazakhstan (Dill, 2011). The positive correlation between $U$ and $P$ in the Walchia shale is also an indicator of reducing conditions during $U$ accumulation, since $U$ is able to incorporate phosphates in a reductive medium (Baturin and Kochenow, 2011 and references therein) as confirmed here by high $\mathrm{HI}$ values (Fig. 3 and Appendix 1).

The $U$ and Th concentrations in the Walchia shale do not correlate with each other $\left(R^{2}=0.29\right.$; Appendix 1$)$, which suggests that they have been derived from independent sources. Uranium is most likely derived from underlying oxidized sediments of the Rotliegend strata, while Th is presumably related to clay minerals and tuffs (Piestrzyński, 1989). The geochemical $S_{2} / S_{3}$ ratio plotted against the $U$ and Th content reveals inverse correlation indicating a decrease in organic matter content with increasing concentration of radioactive elements (Fig. 7). Similar phenomena have been observed in the Dictionema Shale by Kosakowski et al. (2017) who explained this by decay of radioactive elements causing polymerisation and oxidation by organic structures. The trend observed in the present study is similar to that seen in the Dictionema Shale; however, the TOC and U contents reported by Kosakowski et al. (2017) are on average several times higher. This suggests that organic matter in the Walchia shale might have been altered to some extent by decay of radiolytic elements. Moreover, the $U$ concentrations correlate with MinC contents (Appendix 1 ), which suggests that $U$ is accumulated in carbonaceous matter which may be associated with phosphates. No correlations between TOC content and Th and Cu concentrations, nei-

Fig. 5. Total organic carbon content versus concentrations of $\mathrm{U}(\mathrm{A})$, Th (B), Cu (C), Ni (D), V (E), Pb (F) and $\mathrm{Zn}(\mathrm{G})$ measured in the Walchia shale samples

Key for sample codes see Appendix 1 


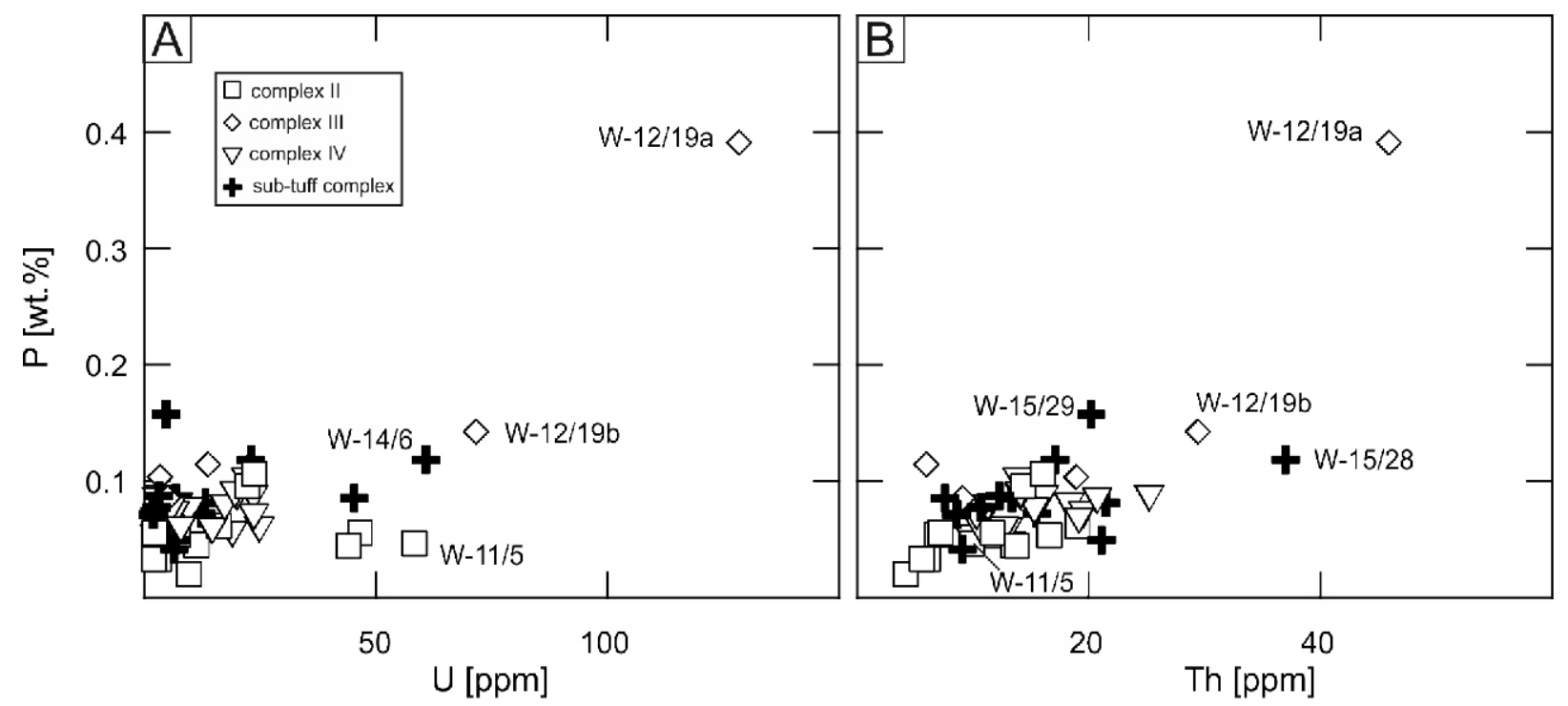

Fig. 6. Total $P$ versus $U(A)$ and Th $(B)$ concentrations

Key for sample codes see Appendix 1

ther for the whole rock population nor for individual lithological complexes, have been observed (Fig. 5B, C).

The abundance of $\mathrm{Cu}, \mathrm{Ni}, \mathrm{V}, \mathrm{Pb}$ and $\mathrm{Zn}$ in the Walchia shale is observed within the whole profile; however, their concentrations correlate with neither TOC (Fig. 5C-G), $\mathrm{HI}$ and $\mathrm{OI}$ values nor $\mathrm{U}$ and Th contents (Appendix 1). The nickel and $\mathrm{V}$ concentrations vary from 17.7 to $83 \mathrm{ppm}$ and from 31 to 255 ppm (Table 1, Appendix 1, Figs. 4D, E, 5D, E), respectively, and do not demonstrate correlations with total S (Appendix 1). Both metals show positive correlation with Fe (Appendix 1) suggesting their association with Fe minerals. Nickel and $\mathrm{V}$ commonly occur in organic matter as $\mathrm{Ni}$ and $\mathrm{V}$ porphyrins.

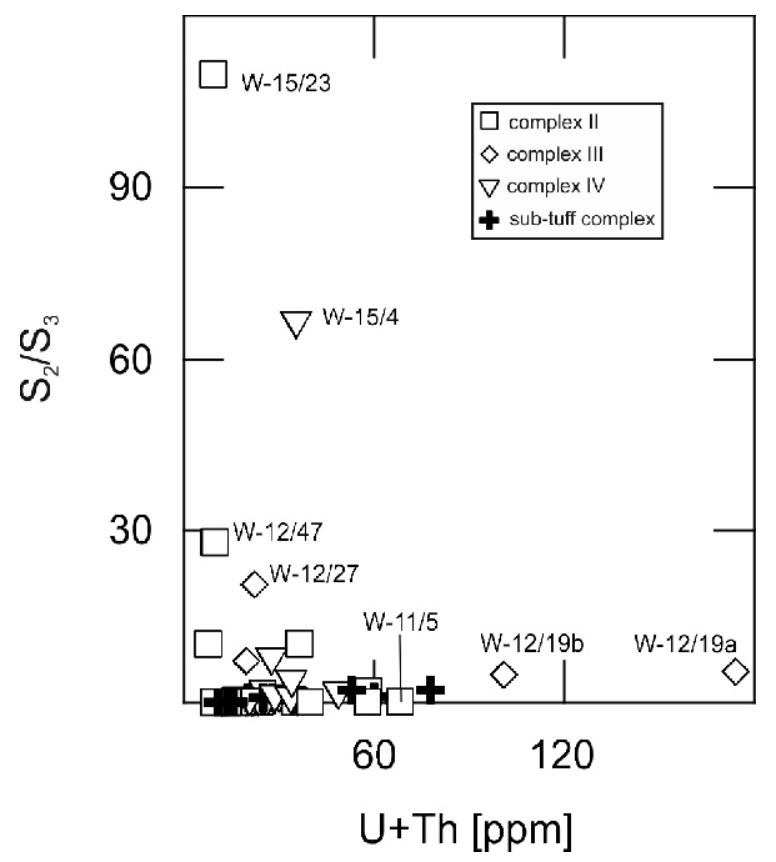

Fig. 7. $S_{2} / S_{3}$ index versus $U$ and Th contents

Key for sample codes see Appendix 1
Nickel, after organic matter degradation related to oxidative alteration, can be retained within a rock in association with pyrite (e.g., Tribovillard et al., 2006). Vanadium and Ni can also be incorporated into clay minerals, as observed in the Kupferschiefer (Bechtel et al., 2002). The nickel concentrations measured in the Walchia shale samples exceed more than twice the values published by Mastalerz (1996) for Rotliegend lacustrine deposits of the ISB.

The results obtained for $\mathrm{Pb}$ and $\mathrm{Zn}$ are significantly higher than those reported by Mastalerz (1996) for lacustrine deposits of ISB, or by Wołkowicz (1992) for the Walchia shale, reaching a maximum of 5166 and 7162 ppm, respectively (Table 1, Appendix 1, Figs. 4F, G, 5F, G). Their occurrence correlates very well with each other indicating their presence in sulphide mineral paragenesis.

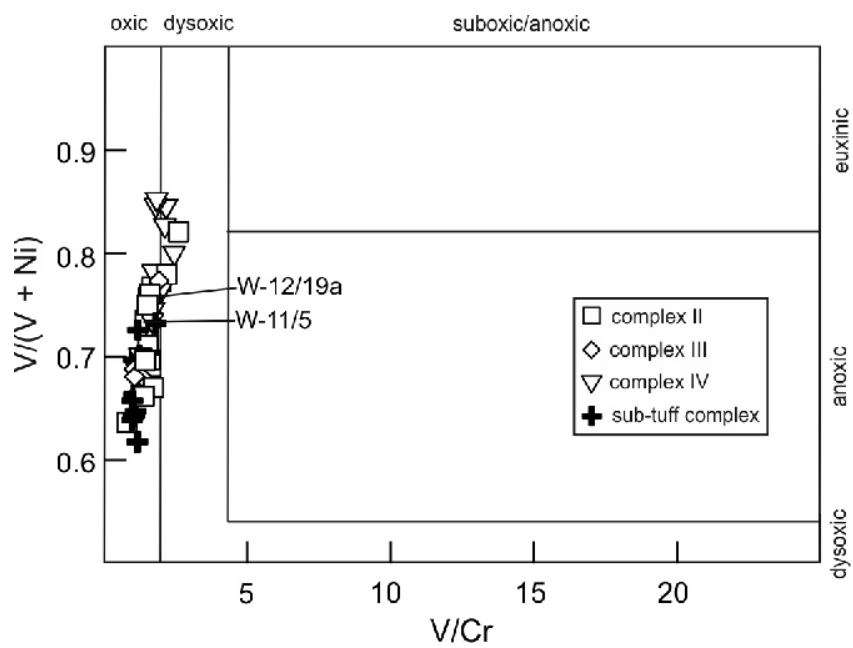

Fig. 8. $\mathrm{V} /(\mathrm{V}+\mathrm{Ni})$ versus $\mathrm{V} / \mathrm{Cr}$ plot for the Walchia shale samples

Ranges of depositional settings from Hatch and Leventhal (1992) and Jones and Manning (1994); diagram after Lecomte et al. (2017); key for sample codes see Appendix 1 


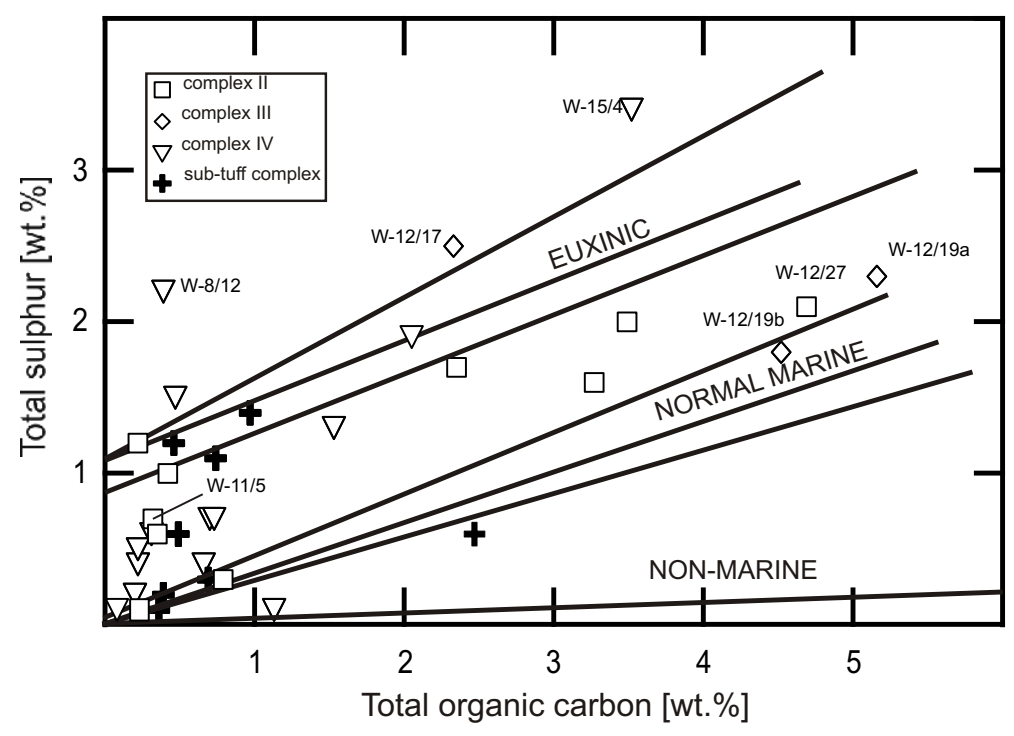

Fig. 9. Plot of total sulphur content versus total organic carbon of the Walchia shale samples, showing environmental conditions (Leventhal, 1993)

Key for sample codes see Appendix 1

The cobalt concentrations are up to $47 \mathrm{ppm}$ and correspond to $\mathrm{Ni}$ and $\mathrm{V}$ contents, and also poorly to $\mathrm{Cu}$ and Fe (Appendix 1). The $\mathrm{Co}$, similarly to $\mathrm{Ni}$, can be associated with pyrite (Bechtel et al., 2002). The Co contents are higher than the average for black shale (10 ppm; Vine and Tourtelot, 1970); however, they are lower than those reported in the Anthracosia shales (Speczik et al., 1995), Kupferschiefer (Sun and Püttmann, 1997) and Alum Shale (Lecomte et al., 2017).

Some trace elements, such as $\mathrm{U}$, Th, Ni, V, Mo, Co, Cr and their ratios, have been widely used for identification of diagenetic redox environments due to their lower solubility under reducing conditions, resulting in precipitation under oxygen-depleted sedimentary conditions (e.g., Hatch and Leventhal, 1992; Jones and Manning, 1994; Zhou and Jiang, 2009; Zhou et al., 2012; Wójcik-Tabol, 2015; Lecomte et al., 2017; Mouro et al., 2017). The Mo concentrations demonstrate a general increase with increasing TOC content, and range from 0.4 to $59 \mathrm{ppm}$, attaining even $609 \mathrm{ppm}$ in one sample representing complex II (Appendix 1). Mo concentrations indicate variable redox conditions during deposition of the Walchia shale (e.g., Mouro et al., 2017). The V/(V + Ni), V/Cr, U/Th, and Ni/Co ratios have been applied to evaluate the presence or absence of dissolved $\mathrm{O}_{2}$ or $\mathrm{H}_{2} \mathrm{~S}$ in the water column during deposition of the Walchia shale. The $\mathrm{V} /(\mathrm{V}+\mathrm{Ni})$ values are within the range of 0.62-0.85 (Appendix 1, Figs. 4H and 8) indicating anoxic to euxinic sedimentary conditions, while the $\mathrm{V} / \mathrm{Cr}$ values vary from 0.76 to 2.55 (Appendix 1, Figs. $4 \mathrm{I}$ and 8 ) suggesting oxic and partially dysoxic bottom conditions, which agree with the U/Th and $\mathrm{Ni} / \mathrm{Co}$ ratios ranging from 0.13 to 6.0 and 1.63 to 5.3 , respectively (Appendix 1, Fig. 4J; Jones and Manning, 1994). The discrepancy in evaluation of depositional conditions may suggest that not all used redox proxies are reliable and can be employed in the discussed case, as indicated also by the lack of correlation between them (Appendix 1).

The plots of total organic carbon content and total sulphur content have been commonly used to discriminate between oxic, anoxic and euxinic environments (e.g., Leventhal, 1993 1995; Jones and Manning, 1994; Sun, 1998; Lecomte et al., 2017). The TOC/S ratios obtained for Walchia shale samples vary to a large extent from 0.18 to 15 (Fig. 9). Positive correlation, mostly along euxinic sediments, indicates syngenetic and diagenetic sulphide formation by microbial sulphate reduction and reaction of sulphide with reactive Fe (Leventhal, 1995). A similar pattern has been revealed for samples from the Polish and German Kupferschiefer by Lewan et al. (2008) and Bechtel et al. (2001), respectively. The positive intercept with the total S axis may evidence the formation of pyrite in the water column and at the water-sediment interface (Lecomte et al., 2017). Some of the samples plot a vertical trend along the S-axis, indicating S-rich TOC-poor sediments. Such phenomenon has been observed by Sun (1998) in Kupferschiefer samples.

The base metal distribution within the Walchia shale is similarly patchy within the whole profile. The metal occurrence seems to be limited to the fine-grained sediments within complexes without sandstone and coarse-grained layers. This observation suggests post-depositional mechanisms of metal arrangement related to the movement of metal-bearing oxidized fluids leaching metals from the Rotliegend and possibly also adjacent volcanic rocks, which penetrated the whole Walchia shale probably using local fault zones and producing mineralisation in organic and sulphide-rich sediments. The evidences of fluid migration in the study area have been previously reported by Lewandowski (1990), who identified significant transformations of rhyolitic tuffs, resulting in analcimisation caused by low-temperature hydrothermal activity. The metal enrichment in the Walchia shale was induced by (altered during diagenesis) organic matter, and formed a redox barrier that retained metals. Epigenetic character of mineralisation might be difficult to notice due to laminated structure of the Walchia shale. The structure promotes a linear flow, because horizontal permeability is higher than vertical. Similar mineralisation processes have been proposed by Speczik et al. (1995) for the Anthracosia shale and partly for Kupferschiefer strata (summarized by Alderton et al., 2016). Metals in the Walchia shale could have been associated with organic matter; however, weak or lack of correlations between analysed metal concentrations and TOC contents may result from subsequent oxidation and alteration of the latter. Pyroclastics underlying the Walchia shale are characterized by similar values of dose rate as the Walchia shale (Bilkiewicz, 2014), which may indicate these rocks as another potential source of Th. 

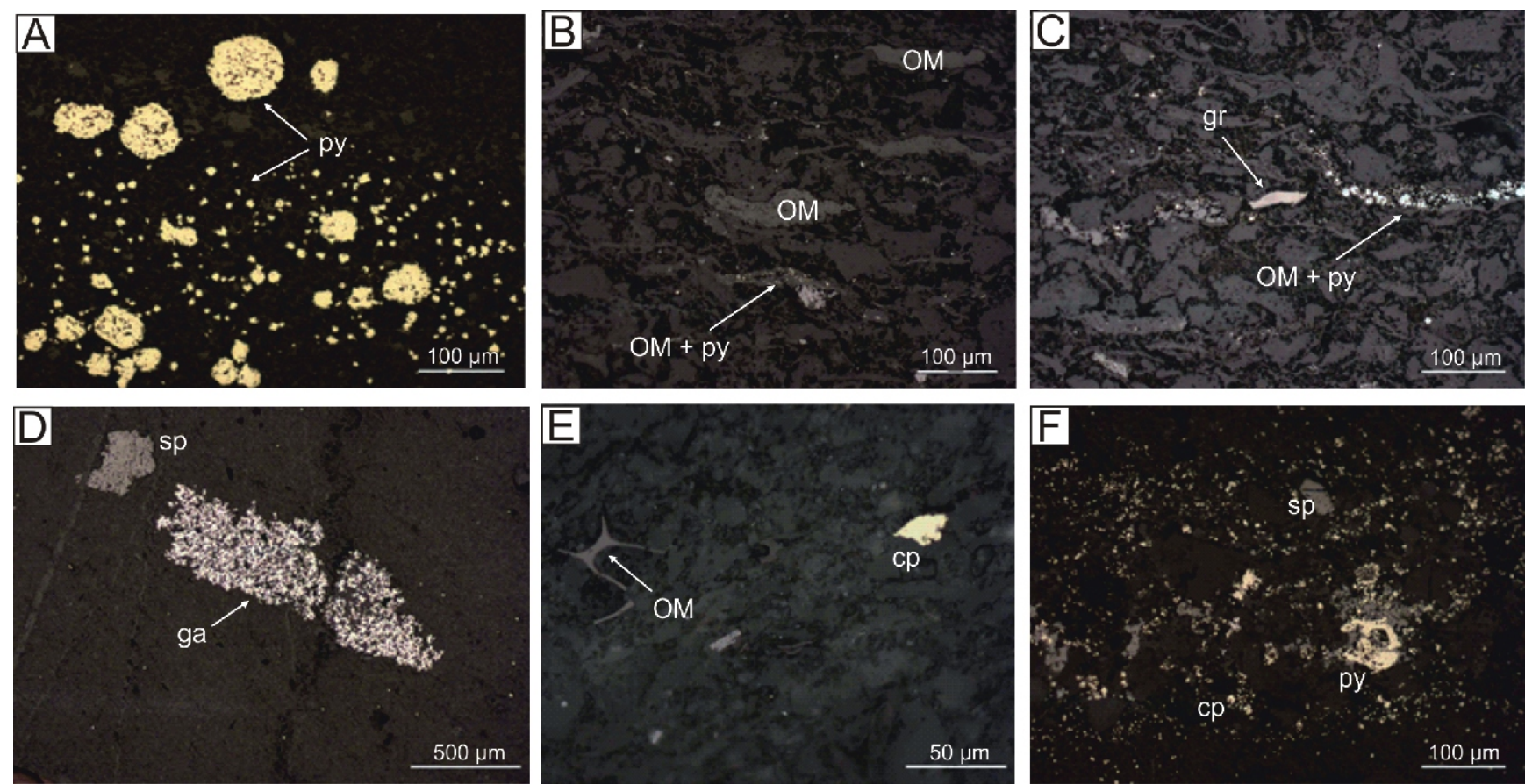

Fig. 10. Microscopic photographs in reflected light

Pyrite (py) framboids, sample W-8/12 (A) clusters of organic matter (OM), one is being replaced by pyrite (py), sample W-15/28 (B), clusters of organic matter (OM), one is being replaced by pyrite (py), graphite (gr) crystal in the centre, sample W-15/28 (C), "pock-marked" structures of galena (ga) and sphalerite (sp), sample W-11/15 (D), chalcopyrite (cp) crystal and organic matter (OM), sample W-11/6 (E), sphalerite (sp), pyrite (py) and chalcopyrite (cp) replacing organic forms, sample W-11/5 (F)

\section{MINERALOGICAL CHARACTERISTICS}

OF THE WALCHIA SHALE

Microscopic investigations showed that most of the analysed samples were mudstones, with minor claystones, containing various amounts of clay minerals and carbonates, mainly in the form of micrite. Previous studies on the Walchia shale (Wołkowicz, 1988, 1990) revealed the presence of framboidal pyrite and occasional hematized and dispersed galena within these sediments.

Microscopy studies in reflected light revealed no detectable occurrence of typical radioactive minerals. Organic matter occurs as irregular thin laminae up to several tens of $\mu \mathrm{m}$. Among the ore minerals the most common is pyrite which occurs in all analysed samples except in sample $\mathrm{W}-12 / 33$, barren in detectable ore minerals. Pyrite forms both euhedral crystals and framboids, which may reach $150 \mu \mathrm{m}$ in size. Framboids are often dispersed throughout the analysed section and commonly scattered forming colonies of various shapes (sample W-8/12, Fig. 10A). The pyrite content in the sections varies from $<0.1$ to $4 \%$ and, in association with marcasite, up to $10.8 \%$ (sample $\mathrm{W}-15 / 20$ ). Pyrite aggregations commonly replace organic matter clusters (Fig. 10B, C), and frequently occur in clay minerals-rich zones (e.g., sample W-15/23) and grow within fractures in quartz (e.g., sample W-15/28). Pyrite also occurs as intergrowths within chalcopyrite. Other common ore minerals are sphalerite and galena, which frequently form mutual intergrowths, locally showing the so-called "pock-marked" structures, in which they replace carbonates and organic matter clusters (samples W-11/15, Fig. 10D). Their quantities within the sections are up to $0.4 \%$ (sphalerite) and $0.2 \%$ (galena). The high $\mathrm{Zn}$ and $\mathrm{Pb}$ concentrations within the Walchia shale samples are therefore related to the common presence of their sulphide minerals. $\mathrm{Cu}$ is associated with chalcopyrite that occured as independent crystals or aggregates up to $75 \mu \mathrm{m}$ (sample
W-11/6, Fig 10E), occasionally forming intergrowths within sphalerite (sample W-15/23). Galena, sphalerite and chalcopyrite may also replace organic forms (Fig. 10F).

Combined EDS and electron scanning microscope investigations were conducted on polished sections of two samples (W-11/5 and $\mathrm{W}-12 / 19 a)$, in which high $U$ concentrations have been observed. The analysis also confirmed the lack of detectable radioactive minerals; however, they confirmed the presence of, not detected in reflected light, apatite (Fig. 11A) occurring also with pyrite intergrowths (Fig. 11B). Apatite shows structural similarity to francolite, a fluorine-bearing variety of apatite, which was reported by Mayer and Piestrzyński (1986) in Weissliegend strata of the Lower Zechstein in the Rudna Mine. Both these samples contain laminae of diagenetic bituminous-type organic matter similar to thucholite observed in the Lubin polymetallic deposit by Piestrzyński (1988). However, organic matter in sample $\mathrm{W}-11 / 5$ is completely different. Organic matter in sample $\mathrm{W}-12 / 19 \mathrm{a}$ is typical sedimentary organic matter (Fig. 11C), whereas that in sample W-11/5 (Fig. 11D) occurs in spaces between mineral grains, being the result of alteration processes related possibly to migrating fluids that were responsible for metal mineralisation of the Walchia shale. Such alteration processes might have enhanced enrichment with metals, especially $\mathrm{Pb}$ and $\mathrm{Zn}$ (Figs. 4F, G and 5F, G).

Results of microscope investigations, including the absence of radioactive minerals, indicate that $U$ and $T h$ in the Walchia shale may be associated with organic matter and phosphate minerals, e.g., francolite-type apatite that is very common in an environment such as represented by the Kupferschiefer (Mayer and Piestrzyński, 1986). The source of phosphorous could be organic matter related to planktonic and algae organisms, which released $\mathrm{P}$ during oxidation-reduction reactions providing it for the precipitation of phosphate minerals. The probable source of $\mathrm{F}$ might be volcanic exhalations. The occurrence of 

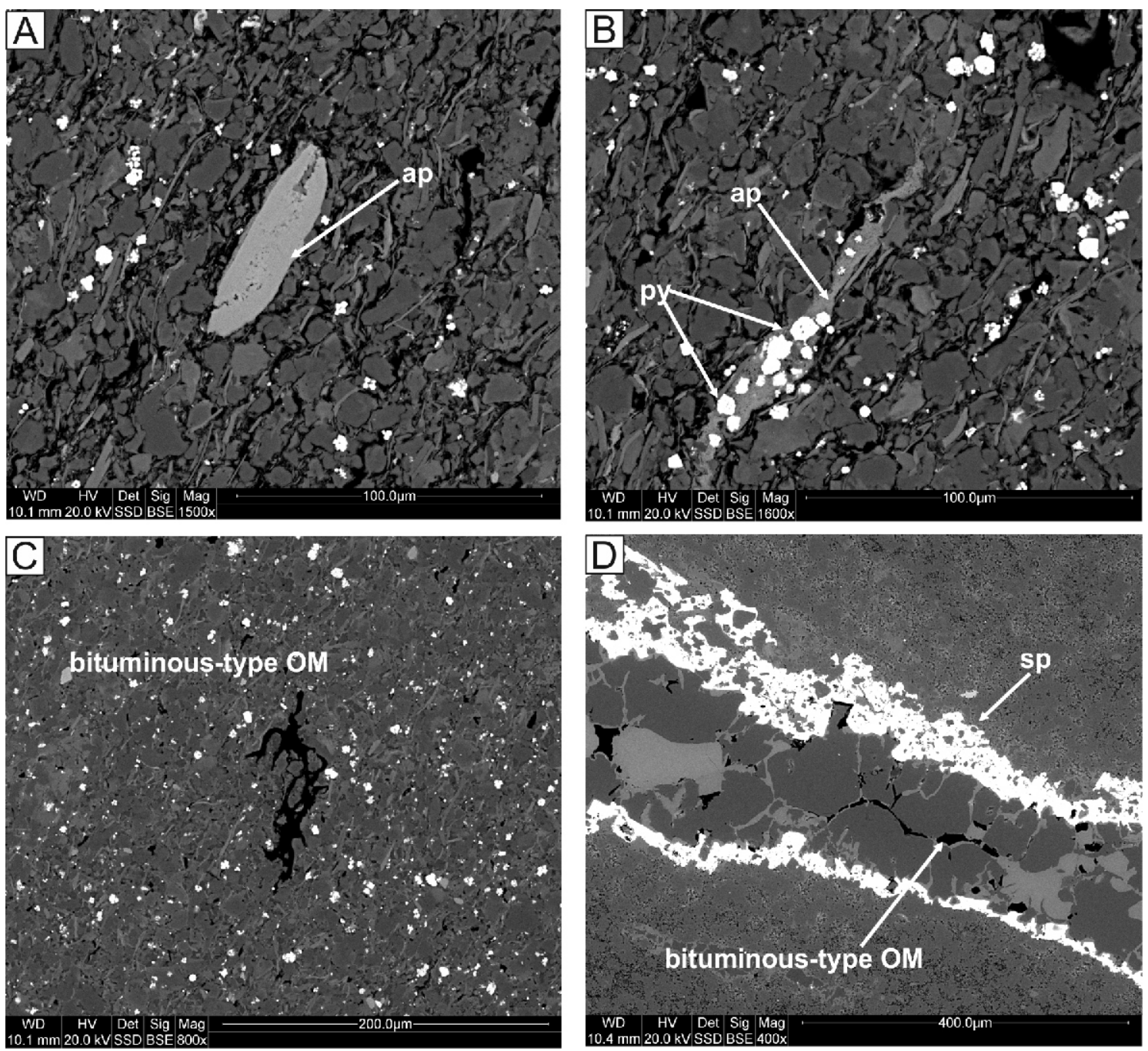

Fig. 11. BSE image of apatite (ap), sample W-12/19a (A), apatite (ap) with pyrite (py) intergrowths, sample W-12/19a (B), bituminous-type organic matter (OM), sample $W-12 / 19 a$ and $W-11 / 5$, respectively (C and $D)$

francolite is characteristic for early diagenetic low-temperature processes (e.g., Mayer and Piestrzyński, 1986).

Stable sulphur isotopic data for framboidal pyrite from Kupferschiefer strata (Pieczonka, 2011) show enrichment in light sulphur isotopes evidencing its organic origin from microbial activity, most likely related to microbial sulphate reduction (MSR). The presence of framboid pyrite and "pock-marked" structures of sphalerite and galena may confirm MSR processes within the Walchia shale, resulting in sulphate reduction, organic matter oxidation, and formation of sulphides under a reducing environment. The enrichment of sulphides in the Walchia shale associated with a relatively high amount of organic matter indicates euxinic and anoxic conditions during sedimentation, which could facilitate precipitation of sulphide minerals from available metals in the water column; however, the definitely higher average concentrations of base metals than the average for black shales indicate post-depositional mineralisation processes related to migration of relatively oxidized fluids from Rotliegend strata.

\section{CONCLUSIONS}

The Walchia shale is generally a poor source rock; however, some parts of the profile, related to deeper, reducing zones of the basin, reveal better source rock parameters, indicating good and even excellent hydrocarbon potential. Results of Rock-Eval pyrolysis indicate predominance of type III kerogen with substantial admixture of planktonic organic matter related to type II kerogen. $T_{\max }$ values correspond to thermally immature organic matter.

The Walchia shale sediments were deposited in a wide lake under variable sedimentary conditions. Most of them were accumulated in a pelagic zone under both anoxic and oxic conditions. The enrichment in organic matter of mixed genetic type indicate that the lake developed in a warm climate and was eutrophic, as also previously concluded by Wołkowicz (1988). The preservation of organic matter within the Walchia shale was most probably caused by the overlying anoxic-euxinic water column that prevented oxidation and favoured synsedimentary concentration of metals. 
Microscopy investigations revealed the lack of radioactive minerals and the common presence of pyrite that occurs frequently in the framboidal form suggesting its organic origin from MSR processes or S-rich organic matter. Galena and sphalerite are widespread within the Walchia shale sequence. No correlation of metal concentrations with TOC content suggests that the metal enrichment could be related to inorganic features of the Walchia shale or had been associated with organic matter which was subsequently oxidized and destroyed, presumably by oxidized solutions penetrating sediments after their deposition.

The Walchia shale system is privileged for metal entrapping due to its reducing character. The elevated concentrations of base metals indicate their epigenetic accumulation. Altered during diagenesis, organic matter acted as a redox barrier for oxidized fluids leaching metals from the Rotliegend and possibly from adjacent volcanic rocks, producing mineralisation in organic and sulphide-rich sediment. Uranium is most likely asso- ciated with organic matter and phosphate minerals, and was delivered by fluids from the underlying Rotliegend strata, while Th is presumably related to clay minerals and/or it migrated from the underlying tuffs.

Acknowledgements. The study has been financially supported by the statutory research of the Faculty of Geology, Geophysics and Environmental Protection at the AGH University of Science and Technology in Kraków, projects Nos. 11.11.140.626 and 11.11.140.320. We thank Prof. $\mathrm{S}$. Wołkowicz for providing geological data of the Walchia shale, helpful comments and editorial work, Prof. M.J. Kotarba for help in research, Mr. H. Zych for analytical work, and Dr. $P$. Kosakowski for assistance in rock sampling. We gratefully acknowledge the reviewers: M. Fabiańska, B. Kříbek and G.J. Nowak for valuable remarks that greatly improved the quality of the paper.

\section{REFERENCES}

Alderton, D.H.M., Selby, D., Kucha, H., Blundell, D.J., 2016. A multistage origin for Kupferschiefer mineralization. Ore Geology Reviews, 79: 535-543.

Augustyniak, K., Grocholski, A., 1968. Geological structure and outline of the development of the Intra-Sudetic Depression. Biuletyn Instytutu Geologicznego, 227: 87-114.

Awdankiewicz, M., Kurowski, L., Mastalerz, K., Raczyński, P., 2003. The Intra-Sudetic Basin - a record of sedimentary and volcanic processes in late- to post-orogenic tectonic setting Geolines, 16: 165-183

Bareja, E., Jęczmyk, M., Kanasiewicz, J., Lis, J., Miecznik, J.B., Sałdan, M., 1982. Radioactive elements in the Sudetes (in Polish with English summary). Biuletyn Instytutu Geologicznego, 341: 259-266.

Baturin, G.N., Kochenov, A.V., 2001. Uranium in Phosphorites. Lithology and Mineral Resources, 36: 303-321.

Bechtel, A., Sun, Y., Püttmann, W., Hoernes, S., Hoefs, J., 2001. Isotopic evidence for multi-stage base metal enrichment in the Kupferschiefer from the Sangerhausen Basin, Germany. Chemical Geology, 176: 31-49.

Bechtel, A., Gratzer, R., Püttmann, W., Oszczepalski, S., 2002 Geochemical characteristics across the oxic/anoxic interface (Rote Fäule front) within the Kupferschiefer of the Lubin-Sieroszowice mining district (SW Poland). Chemical Geology, 185: 9-31.

Bilkiewicz, E., 2014. Radiometric characteristics of rocks occurring in the Radków area (SE part of the Intra-Sudetic Synclinorium). Interdyscyplinarne Zagadnienia w Górnictwie i Geologii, 5: 21-25, Wrocław.

Bossowski, A., Ihnatowicz, A., 2006. Geological atlas of the Lower Silesian Coal Basin 1:100 000. Państwowy Instytut Geologiczny, Warszawa.

Dill, H.G., 2011. A comparative study of uranium-thorium accumulation at the western edge of the Arabian Peninsula and mineral deposits worldwide. Arabian Journal of Geosciences 4: 123-146.

Dill, H.G., Kantor, W.,1997. Depositional environment, chemical facies and a tentative classification of some selected phosphate accumulations. Geologisches Jahrbuch, D 105: 3-43.

Espitalié, J., Laporte, J., Madec, M., Marquis, F., Leplat, P., Paulet, J., Boutefeu, A., 1977. Methode rapide de characterisation des roches meres, leur potential petrolier et de leur degre d'evolution. Oil \& Gas Science and Technology - Rev. IFP, 32 $23-42$.
Espitalié, J., Deroo, G., Marquis, F., 1985. La pyrolyse Rock-Eval et ses applications. Première partie. Oil \& Gas Science and Technology - Rev. IFP, 40-41: 563-579 and 755-784.

Górecka-Nowak, A., 2008. Palynostratigraphy of the uppermost Carboniferous and lowermost Permian sediments in the Sudetes (SW Poland). 12th Internat. Palynological Congress. Terra Nostra 2008/2: 97.

Górecka-Nowak, A., Nowak, G.J., 2008. Charakterystyka petrologiczna i palinologiczna materii organicznej czarnych łupków Sudetów (in Polish). In: Pierwszy Polski Kongres Geologiczny (ed. G. Haczewski): 32, Abstrakty, Kraków.

Hatch, J.R., Leventhal, J.S., 1992. Relationship between inferred redox potential of the depositional environment and geochemistry of the Upper Pennsylvanian (Missourian) Stark Shale Member of the Dennis Limestone, Wabaunsee County, Kansas, U.S.A. Chemical Geology, 99: 65-82.

Hunt, J.M., 1996. Petroleum Geochemistry and Geology. W.H. Freeman and Company, New York.

Jerzykiewicz, J., 1987. Latest Carboniferous (Stephanian) and Early Permian (Autunian) palynological assemblages from the Intrasudetic Basin, southwestern Poland. Palynology, 11: 117-131.

Jones, B., Manning, D.A.C., 1994. Comparison of geochemical indices used for the interpretation of palaeoredox conditions in ancient mudstone. Chemical Geology, 111: 111-129.

Kosakowski, P., Kotarba, M.J., Piestrzyński, A., Shogenova, A., Więcław, D., 2017. Petroleum source rock evaluation of the Alum and Dictyonema Shales (Upper Cambrian-Lower Ordovician) in the Baltic Basin and Podlasie Depression (eastern Poland). International Journal of Earth Sciences, 106: 743-761.

Krauskopf, K.B., 1955. Sedimentary deposits of rare metals. In: Economic Geology, Fiftieth Anniversary Volume (ed. A.M. Bateman): 1905-1955, part I: 411-463. Society of Economic Geologists.

Kurowski, L., 2004. Fluvial sedimentation of sandy deposits of the Słupiec Formation (Middle Rotliegendes) near Nowa Ruda (Intra-Sudetic Basin, SW Poland). Geologia Sudetica, 36: 21-38.

Lafargue, E., Marquis, F., Pillot, D., 1998. Rock-Eval 6 applications in hydrocarbon exploration, production, and soil contamination studies. Oil \& Gas Science and Technology - Rev. IFP, 53: 421-437.

Landais, P., 1996. Organic geochemistry of sedimentary uranium deposits. Ore Geology Reviews, 11: 33-51. 
Lecomte, A., Cathelineau, M., Michels, R., Peiffert, C., Brouand, M., 2017. Uranium mineralization in the Alum Shale Formation (Sweden): evolution of a U-rich marine black shale from sedimentation to metamorphism. Ore Geology Reviews, 88: 71-98.

Leventhal, J., 1993. Metals in Black Shales. Topics in Geobiology, 11. Springer, Boston, MA.

Leventhal, J., 1995. Carbon-sulfur plots to show diagenetic and epigenetic sulfidation in sediments. Geochimica et Cosmochimica Acta, 59: 1207-1211

Lewan, M.D., Kotarba, M.J., Więcław, D., Piestrzyński, A., 2008 Evaluating transition-metal catalysis in gas generation from the Permian Kupferschiefer by hydrous pyrolysis. Geochimica et Cosmochimica Acta, 72: 4069-4093.

Lewandowski, P., 1990. Analcimization of the Lower Permian ryolite tuffs from the Wambierzyce region (Mid-Sudetic Depression). Archiwum Mineralogiczne, 45: 71-85.

Mastalerz, K., 1996. New data on geochemistry of the Rotliegend lacustrine deposits of the Intra-Sudetic Basin (SW Poland) (in Polish with English summary). Przegląd Geologiczny, 44: 1135-1137.

Mastalerz, K., Wojewoda, J., 1988. Rotliegendes sedimentary basins in the Sudetes, Central Europe. In: Rotliegendes Lacustrine Basins (eds. K. Mastalerz and J. Wojewoda). IGCP 219 Meeting, 26-28.10.1988, Książ. Materiały, 1-9. Państwowy Instytut Geologiczny.

Mayer, W., Piestrzyński, A., 1986. Francolite from the Lower Zechstein sediments, Rudna Mine, Fore-Sudetic Monocline. Mineralogia Polonica, 17: 77-84.

Miecznik, J.B., 1989. Uranium mineralization in the Permo-Carboniferous of the Intra-Sudetic Depression (in Polish with English summary). Przegląd Geologiczny, 37: 285-288.

Miecznik, J.B., Strzelecki, R., 1979. The possibility of occurrence of uranium mineralization in some sedimentary formations of the Sudetes (in Polish with English summary). Przegląd Geologiczny, 27: 314-317.

Mouro, L.D., Rakociński, M., Marynowski, L., Pisarzowska, A. Musabelliu, S., Zatoń, M., Carvalho, M.A., Ferndandes, A.C.S., Waichel, B.L., 2017. Benthic anoxia, intermittent photic zone euxinia and elevated productivity during deposition of the Lower Permian, post-glacial fossiliferous black shales of the Paraná Basin, Brazil. Global and Planetary Change, 158 155-172.

Nemec, W., Porębski, S., Teisseyre, A.K., 1982. Explanatory notes to the lithotectonic molasse profile of the Intra-Sudetic Basin Polish Part. Veröffentlichungen des Zentralinstituts für Physik der Erde, Akademie der Wissenschaften der DDR, 66: 267-278.

Nowak, G.J., 2007. Comparative studies of organic matter petrography of the late palaeozoic black shales from Southwestern Poland. International Journal of Coal Geology, 71: 568-585.

Peters, K.E., Cassa, M.R., 1994. Applied source rock geochemistry. AAPG Memoir, 60: 93-102.

Pieczonka, J., 2011. Factors controlling distribution of ore minerals within copper deposit, Fore-Sudetic Monocline, SW Poland (in Polish with English summary). Wydawnictwa AGH, Kraków.

Pieczonka, J., Piestrzyński, A., Mucha, J., Głuszek, A., Kotarba, J., Więcław, D., 2008. The red-bed-type precious metal deposition in the Sieroszowice-Polkowice copper mining district, SW Poland. Annales Societatis Geologorum Poloniae, 78: 151-280.

Piestrzyński, A., 1988. Thucholite from Lubin polymetallic deposit new data. Neues Jahrbuch für Mineralogie Abhandlungen, 160 : 57-60.

Piestrzyński, A., 1989. Uranium and thorium in copper ore deposits on the Fore-Sudetic Monocline (SW Poland). Mineralogia Polonica, 20: 41-56.

Piestrzyński, A., 1990. Uranium and thorium in the Kupferschiefer formation, Lower Zechstein, Poland. Mineralium Deposita, 25 $146-151$.
Quinby-Hunt, M.S., Wilde, P., Orth, C.J., Berry, W.B.N., 1989. Elemental geochemistry of blackshales-statistical comparison of low-calcic shales with other shales. U.S. Geological Survey Circular, 1037: 10-15.

Radwański, S., 1955. Szczegółowa mapa geologiczna Sudetów 1:25 000, arkusz Radków (in Polish). Wyd. Geol., Warszawa.

Schnug, E., Haneklaus, N., 2014. Uranium, the hidden treasure in phosphates. Procedia Engineering, 83: 265-269.

Speczik, S., Bechtel, A., Sun, Y.Z., Püttmann, W., 1995. A stable isotope and organic geochemical study of the relationship between the Anthracosia shale and Kupferschiefer mineralization (SE Poland). Chemical Geology, 123: 133-151.

Sun, Y.-Z., 1998. Influences of secondary oxidation and sulphide formation on several maturity parameters in Kupferschiefer. Organic Geochemistry, 29: 1419-1429.

Sun, Y., Püttmann, W., 1997. Metal accumulation during and after deposition of the Kupferschiefer from the Sangerhausen Basin, Germany. Applied Geochemistry, 12: 577-592.

Tásler, R., Čadková, Z., Dvořák, J., Fediuk, F., Chaloupský, J. Jetel, J., Kaiserová-Kalibová, M., Prouza, V., SchovánkováHrdličková, D., Středa, J., Stř̌ida, M., Šetlik, A., 1979. Geology of the Czech part of the Intrasudetic Basin (in Czech with English summary). Ústředni Ústav Geologický, Praha.

Teisseyre, A.K., 1975. Sedimentology and palaeogeography of the Kulm alluvial fans in the western Intrasudetic Basin (Central Sudetes, SW Poland). Geologia Sudetica, 9: 7-135.

Tribovillard, N., Algeo, T.J., Lyons, T., Riboulleau, A., 2006. Trace metals as paleoredox and paleoproductivity proxies: An update. Chemical Geology, 232: 12-32.

Turekian, K.K., Wedepohl, K.H., 1961. Distribution of the elements in some major units of the Earth's crust. GSA Bulletin, 72: 175-192.

Vine, J.D., Tourtelot, E.B., 1970. Geochemistry of black shale deposits, a summary report. Economic Geology, 65: 235-272.

Więcław, D., 2016. Habitat and hydrocarbon potential of the Kimmeridgian strata in the central part of the Polish Lowlands. Geological Quarterly, 60 (1): 192-210.

Wołkowicz, S., 1988. On the sedimentation of the Lower Permian Walchia Shales from Ratno Dolne (Intra-Sudetic Depression) (in Polish with English summary). Przegląd Geologiczny, 36 214-218.

Wołkowicz, S., 1990. Uranium enrichment in the Permian organic-rich Walchia shale, Intra-Sudetic Depression, southwestern Poland. IAS Special Publications, 11: 217-224.

Wołkowicz, S., 1992. Genesis of uranium mineralization in Lower Permian Walchia shale (Intra-Sudetic Depression) and its facies context (in Polish with English summary). Przegląd Geologiczny, 40: 212-216.

Wójcik-Tabol, P., 2015. Depositional redox conditions of the Grybów Succession (Oligocene, Polish Carpathians) in the light of petrological and geochemical indices. Geological Quarterly, 59 (4): 603-614.

Yawanarajah, S.R., Kruge, M.A., Mastalerz, M., Śliwiński, W. 1993. Organic geochemistry of Permian organic-rich sediments from the Sudetes area, SW Poland. Organic Geochemistry, 20: 267-281.

Zhou, C., Jiang, S.-Y., 2009. Palaeoceanographic redox environments for the lower Cambrian Hetang Formation in South China: evidence from pyrite framboids, redox sensitive trace elements, and sponge biota occurrence. Palaeogeography, Palaeoclimatology, Palaeoecology, 271: 279-286.

Zhou, L., Wignall, P.B., Su, J., Feng, Q., Xie, S., Zhao, L., Huang, J., 2012. U/Mo ratios and $\delta^{98 / 95} \mathrm{Mo}$ as local and global redox proxies during mass extinction events. Chemical Geology, 324-325: 99-107. 